\section{The Perception of Auditors in the Measurement of Instruments Financial Institutions at Fair Value in Financial Institutions}

\author{
Paulo Cesar de Melo Mendes ${ }^{\dagger}$ \\ Universidade de Brasilia, Brasília, DF, Brazil \\ Jorge Katsumi Niyama ${ }^{\Omega}$ \\ Universidade de Brasília, Brasilia, DF, Brazil \\ Cesar Augusto Tiburcio Silva ${ }^{¥}$ \\ Universidade de Brasilia, Brasilia, DF, Brazil
}

\begin{abstract}
The objective of the research is to analyze the auditors' perception regarding the measurement of the fair value of complex financial instruments level 3 in financial institutions. A questionnaire was applied with a sample of 62 independent auditors with technical qualification in financial institutions of large audit firms among partners, managers and senior auditors. The tools used were the Logistic Regression Test (LOGIT); The KruskalWallis test, and the matching analysis test. Subjectivity was an implicit characteristic in the process where the auditors remained conservative. However, differences of values were identified that resulted in immaterial issues and an indication of divergences in the measurement of accounting estimates. As a suggestion of improvement in the audit processes, a more robust academic formation and the inclusion of a financial expert in the teams were identified. Opinions diverge as to the partners and managers, where they pointed out more agreement with the issues than the managers.
\end{abstract}

Keywords: Audit; Measurement; Fair Value; Financial Instruments; Derivatives.

\section{INTRODUCTION}

For almost forty years, fair value has been a standard for assessing assets and liabilities in financial reporting in the standards issued by the Financial Accounting Standard Board (FASB) in more than thirty pronouncements such as measurement of value.

The Statement of Financial Accounting Standards (SFAS) 157 - Fair Value Measurements resulted in the evaluation of assets in an unusual way and allowed the Fair Value Accounting (FVA) to be verified through evaluation techniques in the absence of a market. This resulted in asset reclassifications in balance sheets reversing losses previously recognized and with impacts on stock price in the stock market.

Advocates of the fair value such as (BARTH (1994)(2006); BARTH and LANDSMAN, (2010); PEYTCHEVA and WRIGHT, (2010); GLAVAN (2010) believe that this is the best representation of an entity's financial position by providing greater transparency and relevance of information to its users. Objectors such as (SCHIPPER, (2003); BESTON, BROMWICH and WAGENHOFER, (2006) point
Corresponding author:

† Universidade de Brasília, Brasília, DF, Brazil

E-mail: mendes@unb.br

${ }^{\Omega}$ Universidade de Brasília, Brasília, DF, Brazil E-mail: jkatsumi@unb.br

¥ Universidade de Brasília, Brasília, DF, Brazil

E-mail: cesartiburcio@unb.br

Received: 12/21/2016.

Revised: 05/19/2017.

Accepted: $08 / 10 / 2017$.

Published Online: 05/01/2018

DOI: http://dx.doi.org/10.15728/bbr.2018.15.4.4 
to greater complexity and an inherent judgment of the process with subjectivity, which would facilitate the occurrence of accounting manipulations.

This subjectivity focuses, mostly, on the evaluation of asset groups or isolated assets as in financial instruments, combination of business and asset impairment, which were measured according to the accounting and valuation rules that did not reflect situations of high corporate risk index.

Barth and Landsman (2010) contend stating that the SFAS 157 - Fair Value Measurement - FVM (FASB, 2006) specifies how to estimate market values, limiting the extent of management's ability to manipulate these estimates. The theme is controversial, both for accountants, who are responsible for their measurement, as it is for auditors, who examine these results and can achieve significant effects in the financial statements, with a direct impact on the quality of the accounting information.

These reflexes of distortions of results end up appearing as deficiencies in the quality of the information and are attributable to the measurement of the fair value (FVM) and audit and impairment procedures that impact on certain evaluation deficiencies, as shown in the latest inspection reports issued by the Public Company Accounting Oversight Board (PCAOB) April 2012 and 2013.

To point out the causes in the opinion of the auditors on a debatable, controversial issue such as measurement, is to identify possible failures in the process, to point out the corrections or improvements for the identification of values that are more accurate and with this to minimize the effect of the subjectivity.

So, what are the auditors' perceptions regarding the challenges and difficulties that exist regarding the fair value measurement of complex financial instruments?

The objective of the research is to analyze the perception of the expert auditors in financial institutions, in relation to the measurement of the fair value of complex level 3 financial instruments, in financial institutions in aspects of relevance, measurement and accounting estimates.

This study is divided into five sections, with the first being composed by the introduction with the structural aspects of the study as a characteristic. The second section is composed by the theoretical reference, composed by the main research on the subject. The third section presents the methodology applied in the search of the research construct. The tools used to obtain the data. The fourth part is composed of data collection and analysis of results, and the last section, the completion of the work based on the tests applied.

\section{THEORETICAL FRAMEWORK}

Research on the opinion of auditors in foreign literature is scarce: Pannese and DelFavero (2010); Peytcheva and Wright (2010); Cohen et al. (2011); Kumarasiri and Fisher (2011). In Brazil there is little research: Carvalho (1996), Antunes (1998), Martinez (2008, 2009); Almeida and Almeida (2009); Almeida and Colomina (2009), Braunbeck (2010), Araujo (2011), and Dantas (2012), among others, and focus more on the research on audit rotation and the size of the audit firm (big four) and audit quality.

However, research on the auditor's opinion is unprecedented, and we did not identify any research in this line. To seek the perception of a professional who expresses the opinion on "if" a certain demonstration or evaluation is reasonably correct or not, we believe it is important for the risk mitigation process. There is still a controversy in the literature about measurement at fair value and historical cost, in which arguments that are for and against fair value accounting have been going on for many years. The main argument in favor of the valuation of all assets and liabilities at fair value, is that the metric provides more information to the investor, greater transparency and greater utility of the audit reports, i.e., 
BBR

15,4

fair value accounting can provide a more realistic picture of the financial position than the historical cost.

The argument in favor of reports at historical cost is that it has no subjectivity. Unlike fair value, which may require extensive use of judgment, and often requires evaluation specialist, the historical cost is usually more objective. This makes it easier to prove the assessment and facilitate the work of the auditor.

The auditors expressed support for an accounting system based on principles that would allow a greater judgment on the representation of the financial statements under the economic reality (DiPiazza et al.,(2008). The increase in the accountability of auditors is likely to increase as they perceive that there is a greater requirement for the quality of their judgment and in decision making (PEYTCHEVA; WRIGHT, 2010).

The main argument is that standards based on principles induce a high level of quality in the accountability process by auditors (PEYTCHEVA \& WRIGHT, 2010).

It is important to consider that the effects of applying the regulatory regime under the auditor's efforts restrict aggressive reporting on principle-based accounting rather than rule-based accounting.

It is also relevant to note that an aggressive report may occur in different ways, for example, management may commit fraud, or can structure accounting operations so that the transaction meets the "rule", but not the "spirit" of the rule (NELSON, 2003; NELSON et al., 2002).

Therefore, Cohen et al. (2011) have pointed out that auditors are more likely to restrict aggressive reporting on principles-based standards than rules-based standards. The study by Cohen et al (2011) contributes to a better quality of information in financial reports.

Thus, as a possible alternative and solution to the subjectivity inherent in the evaluation process, the standard tries to restrict its aspects of management, as it is stated by Barth and Lansman (2010).

\subsection{IFRS 13 Fair Value Measurement}

The standard IFRS 13 presents valuation techniques usually used to measure the fair value of unquoted equity instruments with a income approach, as well as the adjusted net asset method. However, it does not prescribe the use of a specific recovery technique, although it does encourage the use of professional judgment and consideration of all factors and circumstances surrounding the measure.

The standard includes examples that illustrate how we can measure the fair value of an unquoted equity instrument by applying the valuation techniques described, although the investor has limited financial information.

IFRS 13 does not contain a hierarchy of use of valuation techniques nor does it prescribe the use of a specific valuation technique to achieve the objective of a FVM. However, IFRS 13 recognizes that, in specific circumstances, one valuation technique may be more appropriate than another. The fair value measurement aspect often requires some form of judgment, and with the convergence of US GAAP with international accounting standards, among other factors, the measurement of fair value and disclosures is a worldwide fact.

The same author points out that the rules are also becoming more complex in their requirement for the measurement of fair value and cites the example by FASB ASC 82510-25 (SFAS 159), fair value option, which increased the complexity of the measurement process.

To try to answer the question of the research, a method is sought that points the opinion of the professional in this existent controversy. 


\section{METHODOLOGY}

Martins and Theóphilo (2009) present the technical aspects of research in conceiving design (delineation, planning, draft, or even drawing). They assert that a construct, or construction, is a variable, or set of variables, which becomes a robust operational definition, which seeks to represent the true theoretical meaning of a concept.

One of the bases of the construct is the questionnaire, a tool we used in this research to obtain the opinion of the auditors. Thus, we performed a pre-test with 10 auditors for adjustments and changes in the questions formulated. Initially we elaborated 55 questions divided in the thematic poles on the deficiencies identified by the PCAOB in the audits of financial instruments evaluated at fair value.

An acceptable level of reliability indicates that the answers to the questions are coherent. Kline (1999, apud FIELD, 2009) notes that although the commonly accepted value of 0.8 is appropriate for cognitive tests such as the intelligence test, for skill tests a cutoff point of 0.7 is more appropriate. Martins and Theóphilo (2009) also corroborate the question stating that when the coefficient is higher than 0.7 , it is said that there is reliability of the measures. The research presented a Cronbach's alpha coefficient of 0.74 , confirming the reliability criterion of the questions.

Validity is the point where a construct measures what it should measure (MARTINS\&THEÓPHILO, 2009). To ensure the validity of the measurement, according to Pasquali (2010),we can use one or more of the following approaches:

a) Content validity, or face validity - involves a systematic, but subjective, assessment of the ability of the scale to measure what it should measure. Validation in general involves consulting a small sample of typical respondents and/or experts for judgment on the appropriateness of the items chosen to represent the construct. We choseMr. Alexandre Dias Fernandes, Audit Director of the Company KPMG, one of the Big Four, indicated in the market of auditors of financial institutions in derivative financial instruments as a specialist in the subject.

b) The second specialist chosen was Prof. Dr. José Alves Dantas, who has studies on the financial market.

c) The third specialist we chose was Prof. Dr. César Augusto Tibúrcio Silva, Professor at UnB, which validated the questions on the statistical and content aspects.

d) Construct validity evaluates what the construct (concept) or scale is actually measuring, and to evaluate construct validity, the research should point to the underlying theoretical foundation. Thus, the theory is used to explain why the scale works and how the results can be interpreted.

We sought as theories that based the research on the concepts and applications on the subject, and we used scientific articles, documents, resolutions and national and international standards on fair value measurement. However, for greater robustness to the theme and according to the logic of the advocates, we used the Efficient Markets Theory and rational expectations hypotheses of the agents.

As results, we identified some interpretations, inconsistencies, complexities and ambiguities in the formulated questions. We reformulated the questionnaire and adjusted it to 25 questions. Pasquali (2010) comments that a good construct must have about 20 items.

In the elaboration of the questionnaire, we consider the semantic analysis of the items; judges analysis and applied the coefficient of Cronbach's Alpha, obtaining index of 0.74, considered consistent according to Pasquali (2010).
BBR

15,4 
BBR

The semantic analysis of the items aims to verify that all items are understandable to all members of the population to which the instrument is intended. Two points were relevant:

a) Verify that items are intelligible to the lowest (skill) stratum of the target population (independent auditors with experience in bank auditing, trained and active for more than 2 years with reasonable knowledge in account assignment)who could comment on whether the items were clear and easy to understand;

b) Lack of objectivity in the formulation of the items, whose semantic analysis must be done with a more sophisticated sample (of greater ability) of the target population to guarantee the so-called "apparent validity"(audit partners, managers and seniors with over 4 years of service, with reasonable knowledge of financial instruments).

Despite the concern of the two points, we also carefully evaluated the magnitude of the attribute to which the items referred, for this purpose, we applied it in a small group of auditors, two from KPMG, one from PriceWaterHouseCoopers, and two representatives of companies registered with the CVM, with the national register of independent auditors (CNAI), for a brainstorming situation. This work methodology was very efficient for the final result, where we were able to adjust the questionnaire.

Judicial Opinion, also known as analysis of the judges, rather known as construct analysis, where it is sought to evaluate if the items are referring or not to the trait in question. The objective is to seek the opinion of judges on verbal comprehension and verbal fluency and correlation of questions.

We carried out the analysis with the same group, who opined on the divergent points in the questions. With the analysis of the judges, we elaborated the statistical validation of the construct.

The questions developed for this research were qualified as positive ones of increasing order, elaborated in order to qualitatively identify the opinion of the auditor, with point 1 being assigned for Totally Disagree, 2 for Partially Disagree; 0 for Neither Disagree nor Agree, 3 Partially Agree and 4 for Totally Agree.

The survey was divided into 3 groups in order to obtain a better result on the choice of the main characteristics on the measurement of the fair value in the opinion of the independent auditor, not including the descriptive analysis of the respondent's profile to identify demographic data, such as gender, age, educational level, training area and qualification of the independent auditor and his/her professional experience, and represented questions no. 01 to 06 .We then divide into knowledge groups of the "fair value" question, as follows:

a) The first group sought to identify the main deficiencies in the process of recognition of financial assets at fair value.

b) The second group sought to point out possible divergences in the process of evaluating accounting estimates between the auditor and the company's management and its final result.

c) The third group sought to identify possible improvements in audit procedures in the valuation of financial assets at fair value.

d) The fourth group sought to point out the variables chosen in the research that may increase the audit risk.

The first group, known as the main deficiencies, had the following topics: 
Issue 7 - Recognition of fair value of financial instruments

7.1 The valuation models used in companies to measure fair value at level 3 are consistent and adequate;

7.2 The basic control principles applied to other financial business activities should not be the same as those applied with derivative transactions;

.3 There is an inherent difficulty in assertions of material change in the value of derivatives;

7.4 Non-observable inputs are subjective and difficult to implement;

7.5 The technological system and the difficulty of identifying the controls of the risks involved are a problem faced by several financial institutions.

\section{Issue 8 - Management Control and Control Risk}

8.1 There is a deficiency of management models and organizational structure for the control of financial instruments;

8.2 An adequate control system is required for derivative transactions, even if such transactions are not relevant to the company;

8.3 An adequate control system for derivative risk management is more important than adequate financial control, because it involves external aspects of control as market risk.

Issue 9 - Difficulty in projecting accounting information

9.1 The problem of evaluation involving subjectivity is the future conditions, transactions or events whose results are uncertain;

9.2 The biggest problem of measuring fair value is the instability of the stock market and capital.

\section{Issue 10 - Fair Value Hierarchy}

\section{Issue 11 Inherent Risk}

11.1 Real-time analysis - timeliness;

11.2 Verification of individual limits - established risk limits;

11.3 Proactive Approach - future behavior analysis of prices and rates;

11.4 Simulations and tests - stress tests.

\section{Issue 12 Inherent Risk}

12.1 Product Volatility;

12.2 Future behavior of prices and rates;

12.3 Leverage of these operations - profits or losses;

12.4 Market Variations.

The second group, known as possible divergences, sought only an affirmative or negative of occurrence:

\section{a) Issue 13 - Divergence of Accounting Estimating Opinion}

b) Issue 14 - Cause of Divergence

14.1 Irrelevant divergences;

14.2 Justified to the point of convincing opinion;

14.3 Maintained disagreements and giving out their opinion with reservation. 
BBR

15,4

The third group with the possible improvements of the auditing procedures pointed out by the auditors themselves on the process of recognition and measurement of financial assets at fair value.

15.1 Absence of clear and sufficient accounting and auditing standards for the adequate development of fair value measurement audit work;

15.2 Absence of professional skepticism from auditors sufficient to perform the audit tests for validation of the fair value evaluations of the financial instruments;

15.3 Lack of involvement of finance specialists in audit teams to address the accounting professional's lack of expertise in evaluating pricing models for financial instruments.

15.4 Lack of tool available on the market to assist audit teams in testing the pricing models of financial assets.

15.5 Failure to supervise and review the audit work performed by team members by an experienced FVM audit professional;

15.6 Academic training in graduation courses in Accounting insufficient for the full development of FVM audit work, considering the audit of financial statements as a private accounting activity.

To analyze the responses, we used the metric scale tool often used in quantitative research. We chose the Likert scale, or added classification scale, to measure attitudes or opinions, developed by Rensis Likert in the early 1930s under the organizational theory.

We sent the questionnaire through "SurveyMonkey", due to the advantages that we find today in this tool, among them: greater speed and possibility of distribution to a large number of potential respondents.

A total of 264 independent auditors were registered on the LinkedIn site, with the qualification deemed necessary to respond to the survey, i.e., they had audit histories in Financial Institutions, and some internal Auditors of Financial Institutions with knowledge in financial instruments.

Through the link: https://pt.surveymonkey.com/s/F9THWJC, where we were able to identify: a) 122 auditors of KPMG Auditores Independentes; b) 53 auditors of PriceWaterHouse (PWC); c) 39 auditors of Deloitte Touche Tohmatsu Limited; d) 25 auditors of Ernst \& Young Global Limited (EY); e) 4 auditors of Baker Tilly Brasil (today the 5th largest audit firm); f) 2 auditors of BDO Auditores Independentes; g) 17 Bank auditors, among them: 1) 5 auditors of the Brazilian Credit Union System - SICOOB; 2) 3 auditors of Banco do Brasil S.A.; 4) 3 auditors of Caixa Econômica Federal - CEF; 5) 2 auditors of the Central Bank of Brazil - BACEN; 6) 2 auditors of Banco Mercantil do Brasil - BMB; 7) 2 auditors of SAFRA Bank; and h) 2 auditors of other audit firms.

The register on this site allowed the identification of the state, region and country of the connected auditor, we identified 90 from São Paulo, 31 from Rio de Janeiro,7 from New York, 2 from London, Brasília, with 58 respondents, Belo Horizonte with 31; Goiania with 16; Curitiba with 10; Salvador with 5 auditors; João Pessoa with 8, Fortaleza with 4 auditors, Recife with 2 auditors.

With all the efforts employed to collect data from all connected auditors, we obtained a return of $23.49 \%$, representing a sample of 62 respondents, with that being considered satisfactory due to difficulties in obtaining qualified respondents.

The choice for the logistic regression analysis (LOGIT) is justified by the need to estimate the probability of occurrences, or not, of influence on the answers due to the profile of the respondent. 
After the analysis of the responses, we used the ordinal or binomial logistic regression, according to each question, to verify if the profile of the respondent affected the answer of each question. We used the answer of each question as a dependent variable and as independent variables; we used gender, the academic background (undergraduate or postgraduate studies), level of education (from incomplete undergraduate to doctoral degree), time of experience in the profession (below or above four years) and the age and position of the auditor.

Thus, the ordinal or binary categorical nature of the independent variable of gender $(1=$ men; $2=$ women; $)$ and academic background $(1=$ Management; $2=$ Accounting Sciences; $3=$ Economics; 4=Law) level of education (1=Incomplete; $2=$ complete; $3=$ masters; 4= doctorate degree), time of experience in the profession (up to 4 years $=1$; above 4 years $=2)$, age ( $1=$ up to $20 ; 2=(21$ to $25 ; 3=(26$ to 30$) ; 4=(31$ to 35$) ; 5=(36$ to 40$) ; 7=(41$ to $45) ; 8=(46$ to 50$)$ and 9 (above 51$)$ and position of the auditor ( $1=$ Partner; $2=$ Manager; $3=$ Senior).

$$
\ln \left[\frac{P(\text { event } i)}{1-P(\text { event })}\right]=\beta 0+\beta 1 X i+\beta 2 X i+\cdots \beta n X i
$$

Where $\ln$ is the natural logarithm, $P($ event $)$ is the probability of occurrence of the event i, $\beta$ are the estimated coefficients and $X$, the independent variables.

Subsequently, we analyzed the non-parametric statistical tests of the survey using the questionnaire where the logistic regression test (LOGIT) is justified by the need to estimate the probability of occurrence or not of the auditor's attitude and profile to the measurement of financial instruments at fair value in financial institutions.

Logistic regression is a statistical technique that aims to produce, based on a set of observations, a model that allows the forecasting of values taken by a categorical variable, often binary, from a series of continuous and/or binary explanatory variables (HAIR JR. et al., 2009).

We adopted the confidence interval adopted of $95 \%$ in the survey, and the system takes care of each step to examine the variables in the model to see if any should be removed.

The second test applied was the Kruskal-Wallis test, in order to identify the characteristics of each group consisting of more than three components such as the age of the auditors and qualification. It is a non-parametric test used to compare three or more populations. It is used to test the null hypothesis that all populations have equal distribution functions against the alternative hypothesis that at least two of the populations have different distribution functions.

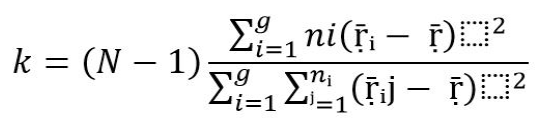

Where:

$\mathrm{n}_{\mathrm{i}}$ is the number of observations in the group ;

$\overline{\mathrm{r}} \mathrm{j}$ is the classification (among all observations) of observations $\mathrm{j}$ in the group $i$;

$\mathrm{N}$ is the total number of observations in all groups;

$$
\begin{aligned}
& \bar{r}_{\mathrm{i}}=\frac{\sum_{\mathrm{i}}^{n_{\mathrm{i}}}\left(\overline{\mathrm{r}}_{\mathrm{i}} \mathrm{j}\right)}{n i} \\
& \overline{\mathrm{r}}=(\mathrm{N}+1) / 2 \text { is the mean of } \overline{\mathrm{r}}_{\mathrm{i}} \mathrm{j} ; K=\frac{12}{N(N+1)} \sum_{i=1}^{\mathrm{g}} \operatorname{ni}\left(\overline{\mathrm{r}}_{\mathrm{i}}-\overline{\mathrm{r}}\right)
\end{aligned}
$$

The third test was the correspondence analysis (CA), which is an exploratory data analysis technique suitable for analyzing tables of two entries or tables of multiple entries, taking into account some measures of correspondence between rows and columns. This method allows studying the relations and similarities between the variables presented in the rows and columns. 


\section{DATA ANALYSIS}

The sample is made up of 14 members of audit firms (28\% of the sample); 21 audit managers (41\% of the sample) and 16 senior (31\% of the sample), and 11 auditors who were classified as audit partners. Graph 1 shows the proportionality of this sample:

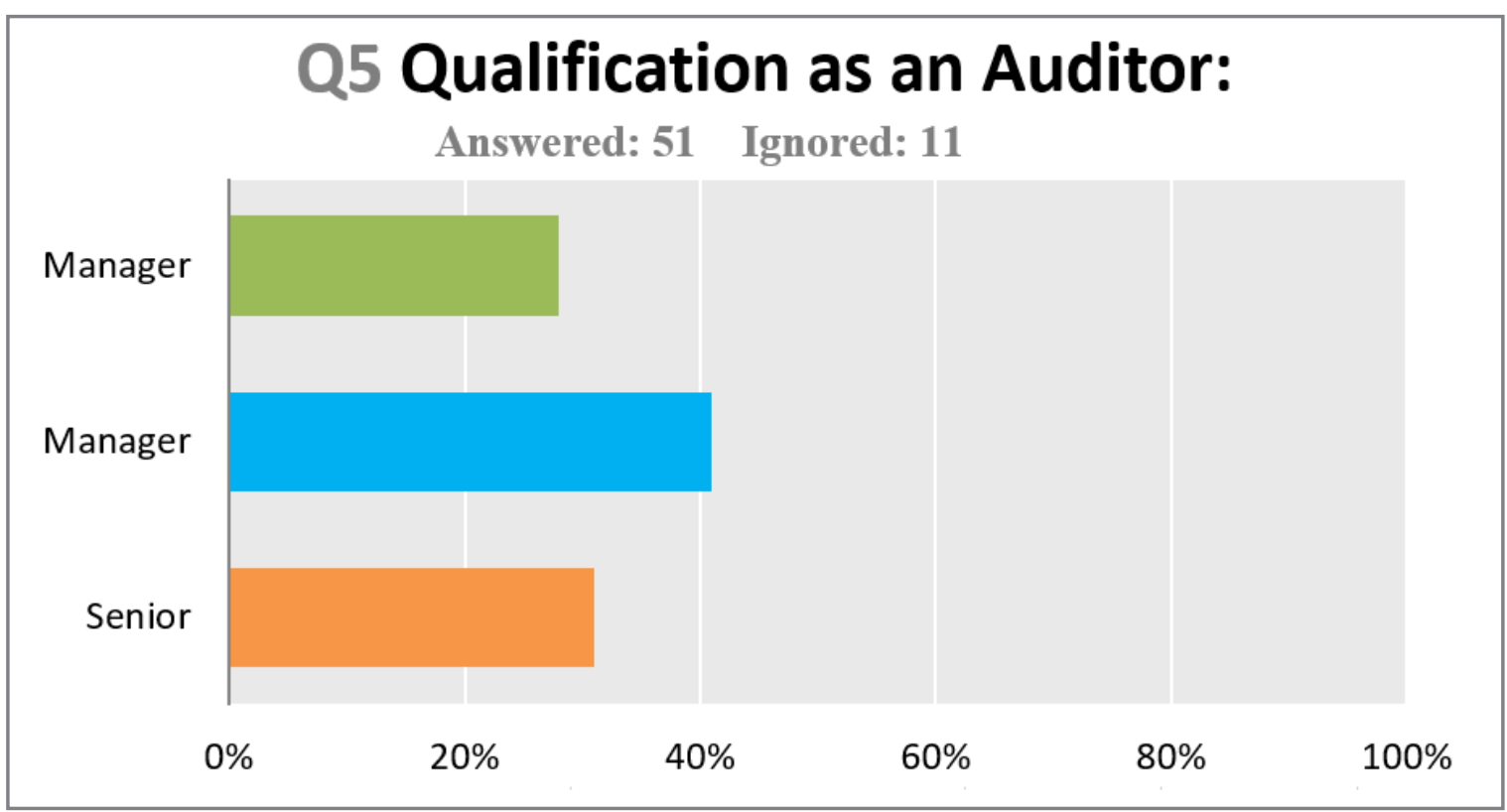

Source: Author's own elaboration.

Graph 1. Qualification as an Auditor.

At the first moment, it is necessary to know the demographic data of the respondents, such as gender, age, level of education, area of training and qualification of the auditor so that later we can use scales and map the profile of respondents. Regarding gender, $87 \%$ of the sample are male, with 52 representatives. The majority are between the ages of 26 and $35 ; 78 \%$ of full-time auditors, $8 \%$ of auditors with masters, and $3 \%$ of auditors with doctorates. Table 1 below shows the proportionality of the gender of the research participants

Table 1. Gender of research participants.

\begin{tabular}{ccc}
\hline Answer options & Answers & \\
\hline Male & $86,67 \%$ & 52 \\
Female & $13,33 \%$ & 8 \\
Total & & 60
\end{tabular}

Source: Author's own elaboration.

After the qualification of the sample, we sought to know the opinion of the independent auditors regarding the measurement and recognition characteristics of the fair value measurement.

\section{Price}

1. Are the valuation models applied in companies for fair value measurement at level 3 consistent and adequate?

Twenty-eight independent auditors were surveyed, representing $47 \%$ of the respondents who agreed partially with the statement, and 18 auditors, representing $30 \%$, responded that they disagreed partially, demonstrating a tendency to consider 
the evaluation models applied as consistent and adequate. $17 \%$ of the sample did not agree or disagree with the question. We believe that in this question the auditor has been more conservative due to the inherent subjectivity.

The application of the Ordinal Logit model showed that the lower the level of instruction, the greater the agreement with the statement $(p$-value $=0.037)$.

\section{The basic control principles applied to other financial business activities should not be the same as those applied with derivative transactions.}

Sixteen auditors answered that they disagree partially with the question, representing $27 \%$ of the sample. 15 auditors replied that they partially agree, accounting for $25 \%$. We observed a deadlock in the issue, with that being considered important for risk analysis. Perhaps a fact of difficult affirmation are the internal controls different from the external controls. None of the characteristics of the respondent influenced the answer of this question, as verified in the Ordinal Logit.

\section{There is an inherent difficulty in assertions of material change in the value of derivatives.}

Thirty-one auditors responded that they partially agree with the question, accounting for $52 \%$ of the sample; 12 auditors replied that they fully agree, representing $20 \%$. The majority of the sample agrees with a difficulty of assertions of material change in the value of derivatives. Due to the volatility of the market, working with abrupt changes reports greater attention. The data also pointed out that respondents from the accounting area agree more strongly with the statement (p-value of 0.0671).

\section{The non-observable inputs are subjective and difficult to implement.}

An issue pointed out as the main characteristic of a process of valuation of derivative assets at fair value. Twenty-eight independent auditors agreed partially with the question, representing $47 \%$ of the sample, and 19 auditors fully agreed, accounting for $32 \%$. Approximately $80 \%$ of the sample agree that the non-observable inputs are subjective and difficult to implement. Again, training in the respondent's accounting area brought greater agreement with the statement of the item (p- value of 0.0026).

\section{The technological system and the difficulty of identifying the controls of the risks involved is a problem faced by several financial institutions.}

This issue pointed to a difficulty in the organizational and control systems for the immediate identification of internal controls related to the existing fluctuation risks on derivatives. Twenty-one auditors fully agreed with the issue, accounting for 35\%; 15 auditors partially agreed, accounting for $25 \%$. The characteristics of the respondent (gender, age, education, experience, training or position) were not individually decisive for the response.

It was possible to observe that the most relevant characteristic of the respondent that affected the answers of the five previous items was the formation or not in the accounting area. To verify, we calculated an Ordinal Logit with the sum of items 1 to 5, previously presented, and the characteristics of the respondent. The result showed that the training in the accounting area was significant ( $p$-value of 0.0142 ).

\section{RISK}

In the second block of the research, the objective was the designation of a system of control of derivative financial instruments in financial institutions that was effective in meeting the information needs of its users, thus ensuring the necessary conditions for risk control. 
BBR

15,4

This management control of operations is important in the process of monitoring and evaluating the asset at fair value. The company that has adequate control reduces the risk of the evaluation process and obtains a more accurate value of reality. Its structure interferes directly with subjective aspects and with "unobservable inputs".

As a result, most auditors agreed that there is a need for an adequate control system for derivative operations, even if those operations are not relevant for the company. However, the research points out that there is no consensus on this issue. Table 2 shows the deficiencies on management control in financial instruments in the opinion of the independent auditors.

Table 2. Managerial Control.

\begin{tabular}{|c|c|c|c|c|c|c|c|}
\hline & $\begin{array}{l}\text { Strongly } \\
\text { disagree }\end{array}$ & $\begin{array}{l}\text { Partially } \\
\text { Disagree }\end{array}$ & $\begin{array}{l}\text { Neither } \\
\text { agree nor } \\
\text { disagree }\end{array}$ & $\begin{array}{c}\text { Partially } \\
\text { agree }\end{array}$ & $\begin{array}{c}\text { Strongly } \\
\text { Agree }\end{array}$ & Total & $\begin{array}{c}\text { Average } \\
\text { rating }\end{array}$ \\
\hline $\begin{array}{l}\text { 1) There is a deficiency of } \\
\text { management models and } \\
\text { organizational structure for the } \\
\text { control of financial instruments }\end{array}$ & $\begin{array}{c}1.72 \% \\
1\end{array}$ & $\begin{array}{c}18.97 \% \\
11\end{array}$ & $\begin{array}{c}32.76 \% \\
19\end{array}$ & $\begin{array}{c}25.86 \% \\
15\end{array}$ & $\begin{array}{c}20.69 \% \\
12\end{array}$ & 58 & 2,00 \\
\hline $\begin{array}{l}\text { 2) An adequate control system for } \\
\text { derivative operations is necessary } \\
\text { even if these transactions are not } \\
\text { relevant to the company }\end{array}$ & $\begin{array}{c}0 \% \\
0\end{array}$ & $\begin{array}{c}3.45 \% \\
2\end{array}$ & $\begin{array}{c}17.24 \% \\
10\end{array}$ & $\begin{array}{c}29.31 \% \\
17\end{array}$ & $\begin{array}{c}50 \% \\
29\end{array}$ & 58 & 2,95 \\
\hline $\begin{array}{l}\text { 3) An adequate control system } \\
\text { for derivative risk management } \\
\text { is more important than adequate } \\
\text { financial control because it } \\
\text { involves external control aspects } \\
\text { such as market risk }\end{array}$ & $\begin{array}{c}6.905 \\
4\end{array}$ & $\begin{array}{c}15.52 \% \\
9\end{array}$ & $\begin{array}{c}29.31 \% \\
17\end{array}$ & $\begin{array}{c}34.48 \% \\
20\end{array}$ & $\begin{array}{c}13.79 \% \\
8\end{array}$ & 58 & 1,97 \\
\hline
\end{tabular}

\section{There is a deficiency of management models and organizational structure for the} control of financial instruments.

Forty-six percent agreed with the question, perhaps because of the subjectivity and varying goals of various companies. As most respondents have the role of audit manager, greater care is assumed in the preparation of work planning, considering audit risks, which are part of the audit planning (SAS 101; ISA 315).

As a complement to the response, some auditors corroborated the assertions about deficiencies in audits carried out, and among the statements the following points stand out: a)the financial institutions are in the process of reviewing the organizational structure; b) there is an executive self-interest in distributed bonuses; c) lack of experience in financial management controls of managers; d) failure of internal controls; e) there are no investment policies; f) there is a non-compliance with regulations; g) an adequate risk assessment system is lacking; and $h$ ) absence of qualified professionals for investment areas.

Respondents with more than four years of experience tended to agree more with this item (p-value of 0.0761): eleven respondents with more than four years of experience reported agreeing with the item versus one with no experience.

\section{An adequate control system is required for derivative transactions, even if such transactions are not material to the company.}

The issue obtained greater agreement of the auditors with $50 \%$ of the respondents, and $29.31 \%$ with partial agreement, representing a relative acceptance of the auditors in $79.31 \%$ of the sample. No auditor disagreed fully with the issue. However, 17.24\%did not agree on the issue, noting that they neither agree nor disagree. For audit purposes, the evaluation of internal controls is fundamental to the existence of the degree of depth and the assessment of audit risk. The respondent's experience was decisive in the responses (p-value of $0.05 \mathrm{of}$ the variable in the ordinal Logit model). 
3. An adequate control system for derivative risk management is more important than adequate financial control because it involves external control aspects such as market risk.

We obtained a percentage of $22.5 \%$ of the auditors that do not agree partially or totally

with an adequate control system of derivative risk management. Perhaps because the financial control is considered greater than the control of derivatives. However, $49 \%$ of the auditors agreed with the statement. Accordingly, the procedures for analytical review of the internal controls contained in AU Section 342 corroborate the mitigation of audit risk, however, as the research indicates, it does not completely remove the flaws in the verification process. Respondents in the accounting area tended to disagree with this assertion ( $p$-value $=0.0453$ ).

\section{FORECAST}

In the third block we sought to know about the difficulties in the projections of financial information, especially in relation to the fair value of financial instruments. The technique of projection of financial information is important to the process of valuation of financial instruments due to market volatility. This issue was considered deficient by the PCAOB in relation to the audit of financial instruments at fair value (ACUITAS, 2012). Table 3 identifies the proportionality of the difficulties in existing Financial Projections.

Table 3. Difficulty in Financial Projections.

\begin{tabular}{|c|c|c|c|c|c|c|c|}
\hline & $\begin{array}{l}\text { Strongly } \\
\text { disagree }\end{array}$ & $\begin{array}{l}\text { Partially } \\
\text { Disagree }\end{array}$ & $\begin{array}{l}\text { Neither } \\
\text { agree nor } \\
\text { disagree }\end{array}$ & $\begin{array}{l}\text { Partially } \\
\text { agree }\end{array}$ & $\begin{array}{l}\text { Strongly } \\
\text { Agree }\end{array}$ & Total & $\begin{array}{c}\text { Average } \\
\text { rating }\end{array}$ \\
\hline $\begin{array}{l}\text { 1) The problem of evaluation involving } \\
\text { subjectivity is the future conditions, } \\
\text { transactions or events whose outcome } \\
\text { is uncertain. }\end{array}$ & $\begin{array}{l}5.17 \% \\
3\end{array}$ & $\begin{array}{c}8.62 \% \\
5\end{array}$ & $\begin{array}{c}13.79 \% \\
8\end{array}$ & $\begin{array}{c}32.76 \% \\
19\end{array}$ & $\begin{array}{c}39.66 \% \\
23\end{array}$ & 58 & 2,79 \\
\hline $\begin{array}{l}\text { 2) The biggest problem with Fair Value } \\
\text { Measurement is the instability of the } \\
\text { Stock and Capital Market }\end{array}$ & $10,34 \%$ & $\begin{array}{c}25.86 \% \\
15\end{array}$ & $\begin{array}{c}18.97 \% \\
11\end{array}$ & $\begin{array}{c}34.48 \% \\
20\end{array}$ & $\begin{array}{c}10.34 \\
6\end{array}$ & 58 & 2,07 \\
\hline
\end{tabular}

\section{The problem of evaluation involving subjectivity are the future conditions, transactions or events whose result is uncertain}

Twenty-three auditors agreed fully with the question, representing 38\%, and 19 auditors partially agreed, representing $32 \%$. Most auditors agreed that the major problems are associated with future conditions, transactions or events whose result is uncertain. Respondents trained in the accounting area had a greater tendency to agree with this assertion ( $p$-value $=0.0688$, in the logit model).

Thus, as in the research conducted by Acuitas Inc. (2012), it is inferred that the economic crisis was the main cause of the increase of audit deficiencies due to the economic volatility, thus undermining the accounting of accounting estimates.

Another highlight in the survey was the significant percentage ( $72 \%$ agreement) indicating that there is a problem of future subjectivity, demonstrating that when designing financial statements it is essential to observe not only the financial information, but also all the factors that influence the results, such as economic conditions, inflation expectations, exchange rate expectations, commodity price forecasts, expected interest rates, availability of credit, changes in the labor market, legal events and political trends.

\section{The biggest problem of Fair Value Measurement is the Instability of the Stock and Capital Market}

The second issue points to the greater problem of measuring fair value, the instability of the stock and capital market. The issue obtained 20 auditors who partially agreed, 
BBR

15,4

375

representing $33 \%$ of the sample. 15 auditors partially disagreed, representing $25 \%$, and 11 auditors neither agreed nor disagreed. The characteristics of the respondent did not influence the response, according to the Logit model.

\section{DisCLOSURE}

In the fourth block, we sought the opinion of the auditor as to whether or not to classify the fair value at levels 1, 2 or 3. The literature indicates that indeed, as according to the classification the evaluator should adopt the method related to the approaching of costs, income or market (ZYLA, 2010). Thirty-five auditors answered that the classification was relevant in this process, representing $59 \%$ of the sample. Thirteen auditors answered that it was very relevant, accounting for $22 \%$. Most agree with the importance of classification.

Notes by the PCAOB (AU SECTION 328) point out that the risk of material misstatement in a fair value valuation process is higher using the higher levels of inputs.

The importance of the fair value classification is to associate inputs with the levels of approach to reduce the risk of evaluation, because in maintaining an evaluation criterion, the risk is lower (ZYLA, 2010). In the market approach, for example, multiple methods are more widely used, where prices or indices can be associated with comparable and similar firms. Under the cost approach, associated to level 2, the methodology is that of replacement cost, and under the income approach, associated with level 3 , the evaluation is focused on the invested return.

In another part of the questionnaire, there was scope as to the existence or otherwise of divergences of opinions on accounting estimates. Fifty auditors stated that they have already had divergences in accounting estimates with the audited company's management, representing $86 \%$. Twenty-four auditors pointed out as a motive the lack of relevance or as material error. Thirty-one percent of the sample stated that the divergences were maintained and were pointed out in the audit reports as provisos caveats. Nine auditors pointed out that the justifications presented by the administration were sufficient. However, apparently the characteristics of the respondent did not interfere in the choice. This block was based on US research (NELSON et al., 2002;LIBBY et al., 2002). Table 4 below shows the proportionality of the divergences noted in accounting estimates between auditors and company management.

Table 4. Divergence of Accounting Estimates.

\begin{tabular}{ccc}
\hline Answer options & Answers & \\
\hline Yes & $86,21 \%$ & 50 \\
No & $13,79 \%$ & 8 \\
Total & & 58
\end{tabular}

Source: Author's own elaboration.

Research by Nelson et al. (2002) and Acuitas (2012) show that the derivatives market has significant divergences in this process. The controversy of the question may be due to a more active and consolidated market than the stock market and national capital, however the answers are consistent with the questions about the evaluation model and risk control system. Table 5 shows the main causes of divergences in accounting estimates.

Table 5. Causes of Divergence in Accounting Estimates.

\begin{tabular}{|c|c|c|}
\hline Answer options & Answers & \\
\hline The divergences were not relevant to the point of considering a material error; & $50 \%$ & 24 \\
\hline The justifications presented convinced your opinion; & $18,75 \%$ & 9 \\
\hline The divergences were maintained and the auditor presented their opinion with caveats in the audit report & $31,25 \%$ & 15 \\
\hline Total & & 48 \\
\hline
\end{tabular}

Source: Author's own elaboration. 
In the last block of the questionnaire, we sought the opinion of the auditor in the process of improvement in the fair value measurement procedures applied:

1) The lack of clear and sufficient accounting and auditing standards for the proper development of fair value measurement work was pointed out by $33.9 \%$ of auditors who partially agreed.

Fifty-seven percent of the auditors agreed with the issue, and $25 \%$ partially disagreed. The research may indicate that the standards process is not fully substantiated to the point of avoiding earnings management, contrary to US research. Another issue is the importance of the standard regarding the commitment of audit work, which apparently should not hinder much. The respondent's age influenced this response: younger people tend to agree with the affirmative (p-value 0.084).

2) The absence of professional skepticism from auditors, sufficient for performing the audit tests for validation of the fair value evaluations of the instruments was considered by most of the respondents as a point to be improved.

Forty-four percent of the auditors partially agreed, and 20\% fully agreed, representing a relative total of $64 \%$ of auditors. However, $22 \%$ of the sample fully disagreed, indicating that there was no problem of professional skepticism, which is an important characteristic that the auditor must have. Higher level of education $(p$-value $=0.0159)$, the best position in the audit area $(p$-value $=0.0106)$ and the male gender $(p$-value $=0.0270)$ were characteristics of the respondent that affected the agreement with this affirmation.

3) The absence of involvement of finance specialists in audit teams to address the accounting professional's lack of expertise in evaluating pricing models for financial instruments.

It was considered by $76 \%$ of the auditors in relative terms, with $42 \%$ partially agreeing and $34 \%$ fully agreeing. Eleven percent partially disagreed. This issue presented the second ranking of agreement by auditors and indicates that there is a problem of finance experts in audit teams. This understanding is corroborated by Catty (2013). The characteristics of the respondent were not decisive in the responses, as determined by the Logit model.

\section{4) Absence of an available tool on the market to assist audit teams in testing the pricing} models of financial assets.

It was considered by $61 \%$ of the sample. Fifteen percent of the auditors did not express an opinion on this issue, neither for nor against. Sixteen percent partially disagreed and $10 \%$ fully disagreed. Just over $25 \%$ of auditors disagree with the lack of available tools. There are consistent instruments for evaluation. There may be a lack of improvement in its use. Older respondents agreed more with this statement $(p$-value $=0.0455$ ).

5) Failure to supervise and review the audit work performed by team members by an experienced FVM audit professional.

Thirty percent of the auditors partially agreed with the issue, and $27 \%$ of the auditors fully agreed. Most of the auditors, representing 57\%, agreed that there is a failure to oversee and review audit work. This process directly involves the quality of the audit process and, as commented in previous surveys, there is still a lot to research on this subject. Twenty-two percent disagreed with the question. The position of the auditor was a relevant characteristic of the respondent: the greater the position, the greater the agreement with the assertive ( $p$-value $=0.0091)$. 

development of the FVM audit work considering the audit of financial statements as a private accountant activity.

$34 \%$ of auditors fully agreed with the insufficiency of the academic training in the courses of Accounting Sciences, and $42 \%$ of auditors partially agreed, accounting for $76 \%$ of auditors. This question was the one that had the highest score of agreement amongst the auditors, being highlighted as the main point in the improvement of the process of evaluation of financial instruments in academic research. Respondents from the accounting area and with more than four years of experience accepted this statement more than the others did ( $\mathrm{p}$-value of 0.006 and 0.0174 , in this order). Younger auditors also ( $\mathrm{p}$-value $=$ $0.007)$ agreed with this assertive.

Although it is considered a descriptive and exploratory technique, CA simplifies complex data and produces exhaustive analyzes of information that supports conclusions about them (HAIR Jr.et al., 2009).

Thus, it is necessary to apply the test in order to describe or map the characteristics of the auditor in the face of fair value measurement issues. These percentage maps indicate in a single step, where the variables and objects are simultaneously represented, where there is directly association of variables and objects. This relationship between object and variables are explicit goals of correspondence analysis (HAIR Jr. et al., 2009).

Cell comparison can identify patterns that reflect associations between certain objects and attributes. Thus, for this purpose, we applied the CA test throughout the questionnaire, however, those variables that presented significance were: a) auditor's qualification; b) auditors' age.

\section{Auditor Qualification Analysis}

The test demonstrates a high significance with the variable 15.1, "Lack of clear rules for work" with 0.008 and a Chi-Square of 22.165. The comparability of the qualification involving the issue demonstrates that most senior auditors and managers agreed with the issue - that the absence of standards could undermine the work of the auditor. However, for the partner or vice president it was divided, with 5 having disagreed and 5 having agreed, and 2 auditors did not give an opinion. In relation to this issue, we assumed that the absence of a standard could not interfere with the professional performance of the auditor, being a subjective issue and of specific evaluation for decision-making.

Another issue is that the rules tend to delimit the subjectivity inherent in the process of fair value. Thus, the test indicates that the majority of auditors do not agree with the norms imposed for subjectivity.

The variable 15.2 "Absence of professional skepticism" presented an even greater significance of 0.003 , with Chi-Square of 24.580. The test demonstrates that the senior auditors agree with the issue along with the partner, however the manager appeared to be divided on the issue, and most of the auditors who responded partially disagree belong to this class of auditors.

In theory, since there is a process of subjectivity, it is believed that skepticism must always prevail in questions.

The variable 15.3 "Lack of involvement of financial experts" presented a high degree of significance with 0.12 and Chi-Square of 21.229, demonstrating the dispersion between the data. Most senior auditors partially agree with the issue along with the partner. The surprise pointed out was the manager representing most of the auditors who did not agree with the issue. A financial expert is critical in this asset valuation and verification process at fair value. 
The issue $\mathbf{1 5 . 5}$ "failure to supervise and review the audit work" was not significant, but obtained an interesting level, with the item selected for evaluation. Senior auditors remained mostly without agreeing or disagreeing, yet most managers agreed that there is a failure to supervise auditors.

Another test that was not statistically significant was issue $\mathbf{8 . 3}$ "an adequate risk management control system", derivative control, for the same reason however, its evaluation is interesting, considering that for the senior auditors it was both representative in the agreement of the question and not to agree with the issue, not showing a representative profile on specific derivative controls. The same occurred with managers, whose majority neither agreed nor disagreed.

In relation to the partner, most agree with specific controls. Most auditors agree with the issue.

\section{ANALYSIS OF THE AUDITOR'S AGE}

The test showed a significance level of 0.053 with a Chi Square 28.667 for the item 8.3, making a parallel with age of greater frequency for the auditors above 35 years old and manager-partner qualification, in which greater care can be assumed in controls for planning work.

The comparability analysis test showed significance with the variable at 0.032 and a Chi-Square of 30.656 for the item 15.2. "Absence of professional skepticism". The issue shows that the majority of the auditors who disagree with the issue are in the age range from 31 to 35 years. Auditors who neither agree nor disagree are in the age group over 50, and the majority who have agreed are in the youngest age bracket of career up to 35 years of age. The younger auditors, aged up to 35 years old, who still perform field work, consider that the absence of professional skepticism could undermine the audit work, which goes against the theory discussed because of the volatility, skepticism and audit risk.

\section{CONCLUSION}

The objective of this article is to analyze the auditor's perception regarding the fair value measurement of complex level 3 financial instruments, in financial institutions, on the aspects of relevance, measurement and evaluation of audit risk.

As the main challenge and deficiency in accounting for FVM, the auditors agreed that the unobservable inputs are subjective and difficult to implement. Regarding the evaluation models applied, it was considered as a deadlock, with a tendency to consider as consistent and adequate.

An issue that drew attention in the research was the causes and divergences of accounting estimates made between the auditors and the administration. Fifty percent of the respondents did not consider disagreements as material, however $31.25 \%$ stated that the divergences were maintained and were subject to reservations in an audit report.

Regarding improvements in the accounting estimates process, the majority indicated as the main reason the fact that academic formation in graduation courses in Accounting as being insufficient for the full development of the audit work of FVM. As a second point, the lack of involvement of a financial expert in audit teams to address the accounting professional's lack of expertise in evaluating pricing models for financial instruments.

The regression analysis indicated that for the accounting graduates, the variables of measurement recognition and derivative control presented significant p-value. For the most experienced auditors (over 4 years of profession), the significant variables were the "basic control principles" and "inherent difficulties in affirmations of changes".

For auditors above 30 years of age, the significant variables were "absence of norms", "absence of specialist involvement". As an improvement, "adequate control system". In the 
BBR

15,4

qualification, a divergence of opinion was pointed out regarding the partner and manager of the audit in the supervision failure issue.

Through the Kruskal-Wallis test, we identified a divergence of opinion between the manager and the audit partner on the issues: a) the consistent evaluation models; b) an adequate control system is required for operations with derivatives; c) the classification of fair value in hierarchy.

For the age group, we identified that auditors above 30 years of age agreed more with the issues than the younger ones in items: a) an adequate control system is required for derivative transactions; b) absence of accounting standards; c) lack of financial expert involvement.

The Correspondence Analysis aimed at a better approximation of the auditors' answers and pointed to the qualification of the auditors the issues: a) absence of accounting standards; b) absence of auditors' professional skepticism; c) lack of involvement of finance specialists in audit teams.

For analysis of the auditor's age, the test was significant by paralleling the age of highest frequency of 35 years and qualification as manager, assuming greater care in controls for the planning of work: a) an adequate control system for derivative risk management; b) absence of auditors' professional skepticism.

The issue shows that the majority of the auditors who disagreed with the issue is in the age group of 31 to 35 years. Auditors who neither agree nor disagree are in the age group over 50, and the majority who have agreed are the youngest career age group with up to 35 years of age. The younger auditors, aged up to 35 years, who still perform field work, consider that the absence of professional skepticism could undermine the audit work, which goes against the theory discussed because of the volatility, skepticism and audit risk.

As recommendations and general closing we can conclude, through the answers collected by the auditors, that some procedures need to be improved such as: a) Stronger academic background in finance and accounting estimates, with more comprehensive courses in their specific hours of work in finance and statistics, b) Failure of internal procedures for supervising and reviewing the roles of audit work performed by team members by more experienced professionals, c) Behavioral failure as absence of professional skepticism, essential in the development of audit work, as well as a more consistent position on controversial and/or subjective issues.

Through the results we can recommend the improvement of accounting estimates techniques for Financial Institutions, as well as the improvement of existing internal controls. Clearer and more objective standards for planning and mitigating audit risk.

The theme is broad and several future lines can be followed, and as an example one can cite a greater concentration on specific accounting events during the crisis and their causes and effects, studies of value relevance on the lack of neutrality of accounting regulation, or studies in the perception of the managers and accountants about a fair value accounting.

\section{REFERENCES}

ACUITAS, INC.'S.Survey of fair value audit deficiencies.April, 2012; http://www.acuitasinc.com/documents/ Survey_of_Big_Four_Fair_Value_Audit_Deficiencies_as_Reported_in_the_Wall_Street_Journal_final.pdf. Acesso em 12/10/2013.

ALMEIDA, J. E. F.; ALMEIDA, J. C. G. Auditoria e-learnings managements: um estudo empírico nas empresas abertas auditadas pelas big four e demais firmas de auditoria. ', USP, São Paulo, vol. 20, $\mathrm{n}^{\circ}$ 50, p. 62-74, maio/agosto 2009;

ALMEIDA, B. J. M.; COLOMINA, C. I. M. Evidencia de las diferencias de expectativas en auditoria em mercados bursatiles de reducida dimension: el caso português. Revista Universo Contábil, Blumenau, vol. 5, no 1, p. 100-114, jan/mar. 2009; 
ANTUNES, J. Contribuição ao estudo da avaliação de riscos e controle internos na auditoria de demonstrações contábeis no Brasil. Dissertação de Mestrado do Departamento de Contabilidade e Atuaria da Faculdade de Economia, Administração e Contabilidade - FEA/USP, 1998.

ARAÚJO, A. M. H. B., MENDES, P. C. M; SILVA, J. D. G. O Comportamento do Auditor Independente diante dos Prazos "Apertados" dos Programas de Auditoria. In: II Congresso Nacional De Administração E Ciências Contábeis - Adcont. 2011, Rio de Janeiro.281, 2011.

BARTH, Mary E. Fair value accounting: Evidence from investment securities and the market valuation of banks. The Accounting Review, 69(1), p. 1-25, 1994.

.Including estimates of the future in today's financial statements. Accounting Horizons: September 2006, Vol.20, no 3, pp 271-285. 2006.

BARTH, Mary E. LANDSMAN, WAYNE R. How did financial reporting contribute to the financial crisis? European Accounting Review, vol. 19, ñ 3, 399-423, 2010.

Benston, G. J. 'Fair-value accounting: A cautionary tale from Enron', Journal of Accounting and Public Policy, 25(4), pp. 465-484. 2006;

BENSTON, G. J.; BROMWICH, M.; WAGENHOFER, A. Principles - Versus Rules-Based Accounting Santandards: The FASB's Santandard Setting Strategy. ABACUS, vol. 42, no. 2, 2006.

BRAUNBECK, G.O. Determinantes da qualidade das auditorias independentes no Brasil. Tese de Doutorado. Programa de Pós-Graudação em Contabilidade- Universidade de São Paulo, 2010.

CARVALHO, L. N. G. Uma contribuição à auditoria do risco de derivativos. Tese de doutorado. Programa de Pós-Graduação em Contabilidade - Universidade de São Paulo/USP. São Paulo, 1996, 121 p.

CATTY, James P. IFRS: Guia de Aplicação do Valor Justo. Tradução: Costa, Francisco Araújo da, Zilio, Leornardo. Porto Alegre. Ed. Bookman, 2013.

COHEN. J., KRISHNAMOORTHY, G., PEYTCHEVA, M., W., A. The Impact of Regulatory Enforcement and the Adoption of Principles-Based Accounting on Auditors' Judgments to Curb Aggressive Reporting. WorkPaper. February 2011.

DANTAS. J. A. Auditoria em Instituições Financeiras: Determinantes de qualidade no mercado brasileiro. Tese de doutorado. Programa Multi-Institucional e Inter-Regional de Pós-Graduação em Ciências Contábeis UnB/UFPB/UFRN, 2012.

; RODRIGUES, F. F.; NIYAMA, J. K. MENDES, P. C. M. Normatização Contábil Baseada em princípios ou em regras? Benefícios, custos, oportunidades e risco. Revista de Contabilidade e Organizações, vol. 4, p.3/9-29, 2010.

DIPIAZZA, J., MCDONNELL, D., SAMYN, F.; FLYNN, T.; QUIGLEY, J. H., TURLEY, J. S., Principlesbased accounting standards. White paper delivered by the CEOs of the International Audit Networks at the Global Public Policy Symposium. 2008 Disponível em: http://www.globalpublicpolicysymposium. com/?s=Principles-based+accounting+standards. Acessoem: 20/10/2012.

FASB. Statement of Financial Accounting Standards 157 - Fair Value Measurements, 2007.—_, FAS 159, The Fair Value Option For Financial Assets and Financial Liabilities Including an Amendment of FASB Statement Number 115, FASB, February 2007

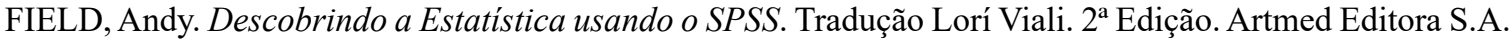
2009

GLAVAN, Silviu. Fair Value Accounting in Banks and the Recent Financial Crisis. Estabilidad Financiera, p. 55-69, 2010.

HAIR JR. et al. Análise Multivariada de dados. Tradução: Adonai SchlupSnta’Anna. $6^{a}$ Edição. Ed. Bookman. 2009

KUMARASIRI, J; FISCHER, R. Auditors' perceptions of fair-value accounting: developing country evidence. International Journal of Auditing. Int.J.Audit.15,p. 66-87, 2011.

LERNER, J. S., TETLOCK, P. E., Accounting for the effects of accountability. Psychological Bulletin, 125 (2), p. 255-275, 1999.

MARTINEZ, A. L. Quando o conselho de administração e auditoria evitam earnings management? Evidências empíricas para empresas brasileiras. $8^{\circ}$ Congresso USP De Controladoria E Contabilidade, 2008. São Paulo: USP, 2008.

. Novo mercado, auditoria e o gerenciamento de resultados por escolhas contábeis e por decisões operacionais no Brasil. $9^{\circ}$ Congresso Usp De Controladoria E Contabilidade. São Paulo: USP, 2009.

MARTINS, G. A; THEÓPHILO, C. R. Metodologia da investigação científica para ciências sociais aplicadas. $2^{\mathrm{a}}$ Ed. São Paulo: Atlas, 2009. 
NELSON, Mark W. Behavioral evidence on the effects of principles- and rules-based standards. Accounting Horizons, vol. 17, $\mathrm{n}^{\mathrm{o}}$ 1, p. 91-104, 2003.

NELSON, Mark W.; Elliott, John; Tarpley, Robin L. Evidence from Auditors about Manager's and Auditor's Earnings Management Decisions. The Accounting Review, vol.77, p. 175-202, Suplement, 2002.

PASQUALI, Luiz, et. Al. Instrumentação Psicológica: Fundamentos e Práticas. Ed. Artmed. 2010;

PANNESE, D., DELFAVERO, A. Fair Value Accounting: Affect On The Auditing Profession. Journal of Applied Business Research, vol. 26, nº 3, p. 43-50, 2010.

PEYTCHEVA, M.; WRIGHT, A. M. The Impact of Principles versus Rules-Based Accounting Standards on Auditors' Motivations and Judgments. Working Paper, 2010.

PUBLIC COMPANY ACCOUNTING OVERSIGHT BOARD (PCAOB).AU SECTION 328. Auditing Fair Value Measurements And Disclosures. SAS 101, SAS 113.

SCHIPPER, Katherine. Principles-Based Accounting Standards. Accounting Horizons, vol. 17, nº 1, p.61-72, 2003. 